\title{
NUTRITIONAL DIAGNOSIS FOR EUCALYPT BY DRIS, M-DRIS, AND CND
}

\author{
Gualter Guenther Costa da Silva ${ }^{1 *}$; Júlio César Lima Neves; Víctor Hugo Alvarez V. ${ }^{1}$; Fernando \\ Palha Leite ${ }^{2}$ \\ ${ }^{1} U F V$ - Depto. de Solos - 36570-000 - Viçosa, MG - Brasil. \\ ${ }^{2}$ CENIBRA S.A - C.P. 100 - 35160-970 - Ipatinga, MG - Brasil. \\ *Corresponding author <gualtergcs@yahoo.com.br>
}

\begin{abstract}
The evaluation of the nutritional status in eucalypt (Eucalyptus grandis W. Hill ex Maid.) forests through vegetal tissue analyses what reflects water and nutrient flows in the system, and represents a complementary tool to soil analysis can be helpful to raise and maintain the forest productivity at high levels. This study compared the use of the Diagnosis and Recommendation Integrated System (DRIS), ModifiedDRIS (M-DRIS), and Compositional Nutrient Diagnosis (CND) diagnose methods in eucalypt stands in Central-Eastern Minas Gerais State, Brazil. Data of productivity and of N, P, K, Ca, and Mg leaf contents in 993 Eucalyptus grandis stands aging between 72 and 153 months, planted on six sites in $3 \times 2 \mathrm{~m}$ spacing, were used. The nutritional status was diagnosed by the DRIS, M-DRIS, and CND methods, and validated by the chi-square $\left(\chi^{2}\right)$ test applied to the nutrients diagnosed as primary limiting by deficiency. These three methods were compared to each other based on the diagnosis concordance frequency (DCF) derived from the fertilization response potential (FRP) by the criteria considering each nutrient separately; from all (5) to none (0); and only the primary limiting nutrients by either deficiency or excess. The diagnosis concordance level among the methods was procedure-dependent, and varied according to the nutrient concentration in trees.
\end{abstract}

Key words: Eucalyptus grandis, leaf analysis, leaf diagnosis, mineral nutrition

\section{DIAGNOSE NUTRICIONAL DO EUCALIPTO PELO DRIS, M-DRIS E CND}

\begin{abstract}
RESUMO: A avaliação do estado nutricional em florestas de eucalipto (Eucalyptus grandis W. Hill ex Maid.), mediante análises de tecido vegetal, pode ser importante para elevação e manutenção em níveis elevados da produtividade florestal, pois, reflete os fluxos de água e de nutrientes no sistema, sendo ferramenta complementar à análise de solo. O presente trabalho foi realizado aplicando-se o Sistema Integrado de Diagnose e Recomendação (DRIS), DRIS modificado (M-DRIS) e Diagnose da Composição Nutricional (CND), com o objetivo de comparar as diagnoses realizadas entre os métodos DRIS, M-DRIS e CND para o eucalipto, em localidades da região Centro-Leste de Minas Gerais. Foram utilizados dados de produtividade e dos teores de N, P, K, Ca e Mg nas folhas, referentes a 993 talhões de Eucalyptus grandis com idades variando de 72 a 153 meses, plantados no espaçamento $3 \times 2 \mathrm{~m}$ em seis localidades dessa região. A diagnose do estado nutricional foi realizada utilizando-se o DRIS, M-DRIS e CND e validada pelo teste do qui-quadrado $\left(\chi^{2}\right)$, aplicado àqueles nutrientes diagnosticados como limitantes primários por deficiência. Os métodos foram comparados, baseando-se na freqüência de diagnoses concordantes (DCF) do potencial de resposta à adubação (FRP), mediante os seguintes critérios: considerando-se os nutrientes separadamente; desde todos (5) nutrientes até nenhum (0); e apenas o limitante primário por deficiência e por excesso. O nível de concordância entre as diagnoses, fornecidas pelos métodos, variou de acordo com o procedimento adotado em sua avaliação e com o grau de concentração de nutrientes nas árvores.

Palavras-chave: Eucalyptus grandis, análise foliar, diagnose foliar, nutrição mineral
\end{abstract}

\section{INTRODUCTION}

The use of the critical level for the evaluation of crops or forests nutritional status is questionable, since it does not define whether the deficiency is acute or not, nor if the nutrient is the most limiting when more than one nutrient is classified as deficient (Baldock \& Schulte, 1996). Furthermore, nutrient tissue contents are influenced by dilution or concentration effects caused by variations in the dry matter yield quantity (Jarrel \& Beverly, 1981).

Diagnosis methods dealing on plant tissue analyses play a key role on precise definition and interpretation of the nutritional plant status, since reveals greater constancy of nutrient relations, compared separately to each nutrient content, as well as in relation to the tissue age (Beaufils, 1973). The Diagnosis and Recommendation Integrated System (DRIS) and the modified DRIS 
stand out among the bivariate diagnosis methods; the Compositional Nutrient Diagnosis (CND) stand out as multivariate method.

The DRIS method, proposed by Beaufils (1973), is based on the comparison of dual relationships (N/P, P/ $\mathrm{K}, \mathrm{K} / \mathrm{Ca}, \mathrm{Ca} / \mathrm{Mg}$, etc.) in samples with standard or norms values. The M-DRIS method (Hallmark et al., 1987) also considers nutrient contents, and not only their dual relationships. On the other hand, the CND method (Parent \& Dafir, 1992), relies on studies developed by Aitchison (1982), which involve statistical composition data analysis, based on the establishment of multinutrient variables (z), weighed by the geometric mean of the nutritional composition.

Consistency of interpretation of plant tissue analysis increases according to the extent by which the univariate approach (of the critical level) is amplified, so that two-by-two relationships (dual relations) between nutrients are observed, (bivariate approach). Progressively, ternary relations are included, until ideally, through multivariate focus, the entire variation structure of the nutritional composition is embraced (Holland, 1966).

The most outstanding studies among the many that use DRIS diagnosis methods are eucalypt Wadt (1996) and Wadt et al. (1998a), for eucalyptus; Hartz et al. (1998) for tomato, and Reis Jr. \& Monnerat (1998) for sugarcane; for M-DRIS, Hallmark et al. (1989; 1990) for soybeans, (Creste et al., 2001) for maize; and for CND, Parent et al. (1994); and Khiari et al. (2001) and for potato, and (Raghupathi \& Bhargava, 1999) for grape. A comparison of the nutritional diagnosis methods, with well-differentiated characteristics of index calculation and interpretations, is fundamental to identify differences between results yielded by each method, allowing an enhanced diagnosis of the nutritional state. The present study compares the use of the methods DRIS, M-DRIS, and CND in eucalypt forests, at sites in the Central-Eastern region of Minas Gerais State, Brazil.

\section{MATERIAL AND METHODS}

Data of productivity and N, P, K, Ca, and Mg contents in Eucalyptus grandis leaves were used. The trees, aging 72 to 153 months, were planted in $3 \times 2 \mathrm{~m}$ spacing at six sites: Cocais, Piracicaba, Rio Doce, Sabinópolis, Santa Bárbara, and Virginópolis, in the Central-Eastern region of Minas Gerais State, in 993 stands. Sites' geographic location and altitude are represented in Table 1.

Data were stratified according to their sites: Cocais $n=191$, Piracicaba $n=201$, Rio Doce $n=54$, Sabinópolis $\mathrm{n}=198$, Santa Bárbara $\mathrm{n}=180$, and Virginópolis $n=169$ stands. The stand population was stratified according to age, in 12-month intervals, counted from the youngest age on. For each age class, mean and standard deviation of the mean annual stem volume in-
Table 1 - Geographic coordinates and altitude of the sites.

\begin{tabular}{lccc}
\hline Site & Latitude & Longitude & Altitude (m) \\
\hline Cocais & $19^{\circ} 23^{\prime} 40.99^{\prime \prime}$ & $42^{\circ} 47^{\prime} 11.13^{\prime \prime}$ & 950 \\
\hline Piracicaba & $19^{\circ} 39^{\prime} 01.94^{\prime \prime}$ & $4^{\circ} 01^{\prime} 07.23^{\prime \prime}$ & 880 \\
Rio Doce & $1^{\circ} 09^{\prime} 33.54^{\prime \prime}$ & $4^{\circ} 25^{\prime} 06.86^{\prime \prime}$ & 480 \\
Sabinópolis & $18^{\circ} 41^{\prime} 09.19^{\prime \prime}$ & $4^{\circ} 56^{\prime} 56.09^{\prime \prime}$ & 880 \\
Santa Bárbara & $20^{\circ} 00^{\prime} 28.72^{\prime \prime}$ & $4^{\circ} 21^{\prime} 50.12^{\prime \prime}$ & 820 \\
Virginópolis & $18^{\circ} 40^{\prime} 03.23^{\prime \prime}$ & $42^{\circ} 30^{\prime} 07.92^{\prime \prime}$ & 860 \\
\hline
\end{tabular}

crease (IMA) were calculated, and the population classified in stands of low and high productivity. The latter was defined as population of reference ( $>\mu+0.5 \mathrm{SD})$.

Diagnosis of the nutritional status were made by the methods DRIS (Beaufils, 1973) and M-DRIS (Hallmark et al., 1987), where all relationships (direct and inverse forms) were taken into consideration. The diagnosis was also made by the Compositional Nutrient Diagnosis (CND) method, according to Parent \& Dafir (1992).

The norms, site-specific and regarding the reference population, consisted in: mean and standard deviation of all dual relations between the studied nutrients for the DRIS; mean and standard deviation of the N, P, K, $\mathrm{Ca}$, and $\mathrm{Mg}$ contents and of all dual relations for the $\mathrm{M}$ DRIS; mean and standard deviation of the multinutrient variables zN, zP, zK, zCa, and zMg; and g(x) (Parent \& Dafir, 1992) for the method CND, calculated as:

$\mathrm{g}(\mathrm{x})=(\mathrm{N} \times \mathrm{P} \times \mathrm{K} \times \mathrm{Ca} \times \mathrm{Mg} \times \mathrm{R})^{(1 / D)} \mathrm{e} \mathrm{z}_{\mathrm{i}}=\ln \left[\left(\mathrm{x}_{\mathrm{i}} / \mathrm{g}(\mathrm{x})\right]\right.$

where $\mathrm{g}(\mathrm{x})=$ geometric mean of the nutritional composition; $\mathrm{N}, \mathrm{P}, \mathrm{K}, \mathrm{Ca}$, and $\mathrm{Mg}=$ respective nutrients contents $\left(\mathrm{g} \mathrm{kg}^{-1}\right)$; $\mathrm{R}=$ value of the complement to $100 \mathrm{~g} \mathrm{~kg}^{-1}$ of dry matter in relation to the sum of $\mathrm{N}, \mathrm{P}, \mathrm{K}, \mathrm{Ca}$, and Mg; $\mathrm{D}=$ number of diagnosed nutrients, including the complement ( $\mathrm{R}) ; \mathrm{z}_{\mathrm{i}}=$ multinutrient variable; and $\mathrm{x}_{\mathrm{i}}=$ nutrient content for which the multinutrient variable is calculated.

For the calculation of the DRIS and M-DRIS functions, Jones' equation (1981) was used as follows:

$$
\mathrm{f}(\mathrm{A} / \mathrm{B})=10[(\mathrm{~A} / \mathrm{B})-(\mathrm{a} / \mathrm{b})] / \mathrm{s}
$$

where 10 = sensitivity coefficient (Black, 1993); $\mathrm{A} / \mathrm{B}=$ dual relation between the " $\mathrm{A}$ " and " $\mathrm{B}$ " nutrient concentrations $\left(\mathrm{g} \mathrm{kg}^{-1}\right)$ of the diagnosed subpopulation; $\mathrm{a} / \mathrm{b}=$ dual relation between the "a" and " $b$ " nutrient concentrations $\left(\mathrm{g} \mathrm{kg}^{-1}\right)$ of the reference subpopulation; and $\mathrm{s}=$ standard deviation of the dual relation of the reference subpopulation. Founded on the values of all DRIS functions, the DRIS index for each nutrient was calculated as follows:

$I A=\bar{f}=[f(A / B)-f(B / A)+f(A / C)-f(C / A)+\ldots . .-f(N /$ A) $] / n$

where $\mathrm{I}_{\mathrm{A}}=$ DRIS index of the nutrient; = mean of the 
DRIS functions; $\mathrm{f}(\mathrm{A} / \mathrm{B})$ and $\mathrm{f}(\mathrm{B} / \mathrm{A})=$ DRIS functions in the direct and inverse forms, respectively; and $n=$ number of DRIS functions (f). Subsequently, the mean nutritional balance index $\left(\right.$ IEN $_{\mathrm{m}}$ ) (Wadt et al., 1998b) for the different sites was obtained by summing up the nutrient indices in a module and by dividing this value by the number of analyzed nutrients.

To calculate the M-DRIS functions and indices, and the dual relations, the nutrient contents were taken into account. In analogy to the establishment of the DRIS indices by means of the nutrient content functions involved in the diagnosis, the M-DRIS dry matter index was obtained too. The following equation allowed the calculation of the $\mathrm{Iz}_{\mathrm{i}}$ indices for the CND method:

$$
\mathrm{Iz}_{\mathrm{i}}=\left(\mathrm{Z}_{\mathrm{i}}-\mathrm{z}_{\mathrm{i}}\right) / \mathrm{sz_{ \textrm {i } }} \text {, }
$$

where $I z_{i}=$ index of the multinutrient variables; $\mathrm{Z}_{\mathrm{i}}=$ multinutrient variable of the diagnosed sample; $z_{i}=$ mean of the multinutrient variable in the reference subpopulation; and $\mathrm{sz}_{\mathrm{i}}=$ standard deviation of the multinutrient variable in the reference subpopulation. As for the IEN ${ }_{\mathrm{m}}$ (Wadt et al., 1998b) calculated for the DRIS, this index was computed for the CND at the different sites. For the DRIS and M-DRIS methods, the function and index calculations were performed with routines developed in Excel 5.0; zN through zMg as well as the CND nutrient indices were also established with Excel 5.0.

The nutritional status diagnosis made by the three methods was statistically validated by the chi-square test $(\alpha=0.10)$ based on the counted frequency of the number of times each nutrient appeared as primary limiting by deficiency. As zero hypothesis $\left(\mathrm{H}_{0}\right)$ was considered the one where this frequency was random-attributed, suggesting that the observed and expected frequencies did not differ from each other; the alternative hypothesis $\left(\mathrm{H}_{1}\right)$ indicates that there are differences between the observed and the expected nutrient frequencies. For each method, the expected frequency was equal to the total number of observations at each site divided by the total number of

Table 2 - Interpretation of the DRIS and CND indices of the nutritional diagnosis in eucalypt plantations in function of the fertilization response potential (FRP).

\begin{tabular}{lccc}
\hline Indice & Module of indice & + LF or + LE & FRP \\
\hline$<0$ & $>$ IEN $_{\mathrm{m}}$ & yes & $\mathrm{p}$ \\
$<0$ & $>$ IEN $_{\mathrm{m}}$ & no & $\mathrm{pz}$ \\
$>0$ & $>\mathrm{IEN}_{\mathrm{m}}$ & yes & $\mathrm{n}$ \\
$>0$ & $>\mathrm{IEN}_{\mathrm{m}}$ & no & $\mathrm{nz}$ \\
$\leq 0$ & $\leq \mathrm{IEN}_{\mathrm{m}}$ & independent & $\mathrm{z}$ \\
$\geq 0$ & $\leq \mathrm{IEN}_{\mathrm{m}}$ & independent & $\mathrm{z}$ \\
\hline
\end{tabular}

$\mathrm{IEN}_{\mathrm{m}}=$ mean nutritional balance index; + LF = most limiting deficient nutrient; + LE = most limiting nutrient in excess; positive (p); positive or zero (pz); negative (n); negative or zero (nz) and zero $(\mathrm{z})$. analyzed nutrients.

The concept of the fertilization response potential (FRP) (Wadt et al., 1998b) was adopted to interpret the DRIS and CND indices (Table 2), and the M-DRIS index (Table 3). The nutrients of the low-productivity stands at each site were therefore classified according to the fertilization response potential: positive (p), positive or zero (pz), zero (z), negative or zero (nz), and negative (n). For easier interpretation of the M-DRIS indices, the adjusted M-DRIS index - the difference between the index of a certain nutrient and of the dry matter - was calculated.

The DRIS, M-DRIS, and CND methods were compared, based on the diagnosis concordance frequency (DCF) derived from the fertilization response potential (FRP), focusing on the following situations: separate nutrients; from all (5) down to none (0); and only for the primary limiting deficient nutrient (p) and excessive nutrient (n). Moreover, low-productivity subpopulation stands were selected at Virginópolis with different nutrient concentration degrees in the trees, considering the IMS (M-DRIS) and G(X) (CND) values, in order to verify the behavior of these methods regarding the diagnose interpretation.

\section{RESULTS AND DISCUSSION}

High productivity stands presented a mean frequency of $30.61 \%$ and low variation among the sites (from 27.8\% in Virginópolis to 33.3\% in Rio Doce) (Table 4), reflecting the statistical criterion used to separate high and low-productivity subpopulations. The percentage increases of stem productivity in the high-productivity stands in relation to the low-productivity ones were the following: Cocais 79.7, Piracicaba 81.9, Rio Doce 51.3, Sabinópolis 73.6, Santa Bárbara 78.2, Virginópolis 52.3, and 70.9 for the all sites. Except for Rio Doce, productivities of the reference population, although not

Table 3 - Interpretation of the M-DRIS indices of the nutritional diagnosis in eucalypt plantations in function of the fertilization response potential (FRP).

\begin{tabular}{lccc}
\hline $\begin{array}{l}\text { Indice M-DRIS } \\
\text { Adjusted }\end{array}$ & $\begin{array}{c}\text { Module of indice } \\
\text { M-DRIS }\end{array}$ & + LF or + LE & FRP \\
\hline$<0$ & $>$ IEN $_{\mathrm{m}}$ & yes & $\mathrm{p}$ \\
$<0$ & $>$ IEN $_{\mathrm{m}}$ & no & $\mathrm{pz}$ \\
$>0$ & $>\mathrm{IEN}_{\mathrm{m}}$ & yes & $\mathrm{n}$ \\
$>0$ & $>\mathrm{IEN}_{\mathrm{m}}$ & no & $\mathrm{nz}$ \\
$\leq 0$ & $\leq \mathrm{IEN}_{\mathrm{m}}$ & independent & $\mathrm{z}$ \\
$\geq 0$ & $\leq \mathrm{IEN}_{\mathrm{m}}$ & independent & $\mathrm{z}$ \\
\hline
\end{tabular}

Adjusted M-DRIS index = nutrient index - dry matter index; IEN $_{\mathrm{m}}$ $=$ mean nutritional balance index; $+\mathrm{LF}=$ most limiting deficient nutrient; + LE = most limiting nutrient in excess; positive (p); positive or zero (pz); negative (n); negative or zero (nz), and zero (z). 
clonal, presented quite satisfactory values (Table 4). Although the studied eucalypt populations aged between 72 and 153 months, stratification according to age class certainly contributed to equalize possible age effect, even though small, in the referred age group.

The norms determined for the DRIS, M-DRIS, and CND methods at the different sites are displayed in Table 5. Note the values of the dual relations and the multinutrient variables differed, in most situations, between high and low-productivity subpopulations, based on the variance ratio or, much more frequently, in relation to the means.

The validation of the diagnosis (norms) is traditionally carried out by factorial schemes, based on fertilization experiments (Caldwell et al., 1994; Payne et al., 1990; Elwali \& Gascho, 1984; Bailey et al., 1997). Because of the lengthy time required to determine results, this kind of validation is more complicated for a crop like eucalypt. In this case, an alternative to validate results is to determine whether the frequencies of the most limiting nutrients (response p) are randomized or not.

In this study, corresponding to the one used by Wadt et al. (1998a), the test of hypothesis was carried out by the chi-square test applied to the counted frequency in which each nutrient appeared as primary limiting by deficiency (response p) at the different sites by the DRIS, M-DRIS, and CND methods. With exception of the Rio Doce site, the referred frequency cannot be attributed to coincidence, in other words, the indices obtained by these methods are viable to evaluate the nutritional status of eucalypt trees (Table 6).

A comparison among the DRIS, M-DRIS, and CND methods was performed by means of specific norms, based on the frequency of concordant diagnoses (DCF) derived from the fertilization response potential (FRP), where three different criteria were taken into consideration. The first criterion considered the nutrients $\mathrm{N}$, $\mathrm{P}, \mathrm{K}, \mathrm{Ca}$, and Mg separately in the DCF evaluation of the FRP, and mean values of $65.0 \%$ (DRIS vs M-DRIS),
86.3\% (DRIS vs CND), and 68.6\% (M-DRIS vs CND) were established for all sites (Table 7). However, for the second criterion, the DCF of the FRP for all sites, considering all (5) nutrients, had means of $17.4 \%$ (DRIS vs MDRIS), $54.3 \%$ (DRIS vs CND), and 20.3\% (M-DRIS vs CND) (Table 8), meaning that, 82.6\%, 45.7\%, and 79.7\% of the stands were diagnosed differently in at least one nutrient, respectively. This kind of comparison expresses the highest level of similarity among the methods.

A third criterion of evaluation was introduced, in a less rigorous but more adequate comparison from a practical point of view. The DCF of the FRP for the primary limiting by deficiency (p), considering all sites, was 77.8\% (DRIS vs M-DRIS), 90.4\% (DRIS vs CND), and $79.0 \%$ (M-DRIS vs CND) (Table 9), whereas the primary limiting by excess (n) was $42.7 \%, 85.6 \%$, and $43.9 \%$, respectively.

As observed for the response " $n$ ", the concordance is smaller when M-DRIS takes part in the comparisons. This results from the fact that, in average, the stands present nutrient dilution, evidenced by the positive dry matter index values (IMS), relative to the DRIS, M-DRIS, and CND index analysis (Silva, 2001). Therefore, the concordance among the methods may vary according to the nutrient dilution (or concentration) degree in the tree according to the diagnosis method. Finally, the M-DRIS (by the IMS) and the CND (by the $\mathrm{G}(\mathrm{X})$ ) provide information on the referred degree. These methods differ, however, in the aspect that M-DRIS uses the IMS as primary reference, while the $G(X)$, in the CND, does not establish any reference for the diagnosis, at least in the way it has been used in the present study. It is therefore fair to suggest that M-DRIS is sensitive to the effects of dilution or concentration, a fact that calls for further comment.

Selected stands of the low-productivity subpopulation of the Virginópolis site with, different nutrient concentration degrees in the trees (Table 10) where thus investigated, as indicated by the values of IMS (M-DRIS) and of $\mathrm{G}(\mathrm{X})(\mathrm{CND})$. The M-DRIS did not detect any limi-

Table 4 - Productivity, number, and mean age of Eucalyptus grandis stands in the Central-Eastern region of Minas Gerais.

\begin{tabular}{|c|c|c|c|c|c|c|c|c|}
\hline \multirow{3}{*}{ Site } & \multicolumn{8}{|c|}{ Subpopulation } \\
\hline & \multicolumn{4}{|c|}{ Low-productivity } & \multicolumn{4}{|c|}{ High-productivity } \\
\hline & Mean & $\mathrm{sd}$ & $\mathrm{n}$ & Age & Mean & $\mathrm{sd}$ & $\mathrm{n}$ & Age \\
\hline & $\mathrm{m}^{3} \mathrm{ha}^{-1} \mathrm{yr}^{-1}$ & & & month & $\mathrm{m}^{3} \mathrm{ha}^{-1} \mathrm{yr}^{-1}$ & & & month \\
\hline Cocais & 23.2 & 8.4 & 129 & 111 & 41.7 & 5.1 & 62 & 112 \\
\hline Piracicaba & 23.8 & 7.3 & 143 & 99 & 43.3 & 10.4 & 58 & 93 \\
\hline Rio Doce & 19.1 & 4.6 & 36 & 101 & 28.9 & 2.7 & 18 & 102 \\
\hline Sabinópolis & 26.9 & 10.4 & 138 & 127 & 46.7 & 8.1 & 60 & 131 \\
\hline Santa Bárbara & 24.8 & 8.6 & 121 & 99 & 44.2 & 7.1 & 59 & 98 \\
\hline Virginópolis & 32.9 & 10.5 & 122 & 117 & 50.1 & 10.2 & 47 & 117 \\
\hline All sites & 25.8 & 9.6 & 689 & 110 & 44.1 & 9.4 & 304 & 110 \\
\hline
\end{tabular}

sd = standard deviation; $\mathrm{n}=$ number of stands per area. 
Table 5 - Mean ( $\bar{Y}$ ) and standard deviation (s) (norms) of the N, P, K, Ca, and Mg leaf contents, of their dual relations, and the $\mathrm{CND}^{1}$ variables in Eucalyptus grandis, subpopulation of high productivity2, at sites in the Central-Eastern region of Minas Gerais.

\begin{tabular}{|c|c|c|c|c|c|c|c|c|c|c|c|c|}
\hline \multirow{2}{*}{ Variable } & \multicolumn{2}{|c|}{ Cocais $\left(n^{4}=62\right)$} & \multicolumn{2}{|c|}{ Piracicaba $(n=58)$} & \multicolumn{2}{|c|}{ Rio Doce $(n=18)$} & \multicolumn{2}{|c|}{ Sabinópolis $(\mathrm{n}=60)$} & \multicolumn{2}{|c|}{ Santa Bárbara $(n=59)$} & \multicolumn{2}{|c|}{ Virginópolis $(n=47)$} \\
\hline & $\overline{\mathrm{Y}}$ & $\mathrm{s}$ & $\overline{\mathrm{Y}}$ & $\mathrm{s}$ & $\overline{\mathrm{Y}}$ & $\mathrm{s}$ & $\overline{\mathrm{Y}}$ & $\mathrm{s}$ & $\overline{\mathrm{Y}}$ & $\mathrm{s}$ & $\overline{\mathrm{Y}}$ & $\mathrm{s}$ \\
\hline & & & & & & & & & & & & \\
\hline $\mathrm{N} / \mathrm{MS}^{3}$ & 18.370 & 0.191 & 19.990 & 0.222 & 18.560 & 0.189 & 20.320 & 0.242 & 20.410 & 0.190 & 20.080 & 0.246 \\
\hline $\mathrm{P} / \mathrm{MS}$ & 0.930 & 0.018 & 1.070 & 0.019 & 1.130 & 0.019 & 1.110 & 0.019 & 1.090 & 0.022 & 1.020 & 0.021 \\
\hline $\mathrm{K} / \mathrm{MS}$ & 9.540 & 0.313 & 9.260 & 0.168 & 9.760 & 0.213 & 9.710 & 0.251 & 9.670 & 0.245 & 9.210 & 0.421 \\
\hline $\mathrm{Ca} / \mathrm{MS}$ & 4.360 & 0.150 & 5.000 & 0.170 & 4.980 & 0.166 & 5.010 & 0.149 & 4.850 & 0.181 & 5.360 & 0.169 \\
\hline $\mathrm{Mg} / \mathrm{MS}$ & 2.110 & 0.049 & 2.110 & 0.058 & 2.070 & 0.055 & 1.940 & 0.068 & 1.950 & 0.058 & 2.180 & 0.071 \\
\hline $\mathrm{MS} / \mathrm{N}$ & 0.550 & 0.058 & 0.506 & 0.056 & 0.544 & 0.053 & 0.499 & 0.060 & 0.494 & 0.044 & 0.505 & 0.056 \\
\hline $\mathrm{MS} / \mathrm{P}$ & 11.080 & 2.010 & 9.650 & 1.630 & 9.070 & 1.510 & 9.260 & 1.490 & 9.500 & 1.630 & 10.140 & 1.850 \\
\hline $\mathrm{MS} / \mathrm{K}$ & 1.161 & 0.384 & 1.118 & 0.223 & 1.075 & 0.250 & 1.110 & 0.341 & 1.094 & 0.257 & 1.214 & 0.372 \\
\hline $\mathrm{MS} / \mathrm{Ca}$ & 2.566 & 0.934 & 2.245 & 0.799 & 2.213 & 0.679 & 2.194 & 0.712 & 2.369 & 0.972 & 2.068 & 0.737 \\
\hline $\mathrm{MS} / \mathrm{Mg}$ & 5.008 & 1.254 & 5.110 & 1.493 & 5.126 & 1.229 & 5.689 & 1.725 & 5.680 & 1.964 & 5.049 & 1.608 \\
\hline $\mathrm{N} / \mathrm{P}$ & 20.080 & 2.620 & 19.060 & 2.480 & 16.690 & 2.250 & 18.600 & 2.320 & 19.180 & 2.540 & 20.030 & 2.620 \\
\hline $\mathrm{N} / \mathrm{K}$ & 2.116 & 0.662 & 2.223 & 0.440 & 1.974 & 0.392 & 2.229 & 0.642 & 2.211 & 0.466 & 2.406 & 0.713 \\
\hline $\mathrm{N} / \mathrm{Ca}$ & 4.722 & 1.832 & 4.524 & 1.809 & 4.061 & 1.198 & 4.526 & 1.765 & 4.873 & 2.200 & 4.138 & 1.527 \\
\hline $\mathrm{N} / \mathrm{Mg}$ & 9.149 & 2.292 & 10.232 & 3.333 & 9.358 & 1.777 & 11.466 & 3.440 & 11.618 & 4.274 & 10.112 & 3.447 \\
\hline $\mathrm{P} / \mathrm{N}$ & 0.051 & 0.007 & 0.053 & 0.008 & 0.061 & 0.009 & 0.055 & 0.007 & 0.053 & 0.007 & 0.051 & 0.007 \\
\hline $\mathrm{P} / \mathrm{K}$ & 0.106 & 0.033 & 0.117 & 0.022 & 0.119 & 0.021 & 0.121 & 0.036 & 0.116 & 0.025 & 0.121 & 0.036 \\
\hline $\mathrm{P} / \mathrm{Ca}$ & 0.241 & 0.106 & 0.240 & 0.100 & 0.248 & 0.083 & 0.248 & 0.108 & 0.261 & 0.129 & 0.210 & 0.083 \\
\hline $\mathrm{P} / \mathrm{Mg}$ & 0.462 & 0.120 & 0.542 & 0.182 & 0.568 & 0.126 & 0.628 & 0.223 & 0.618 & 0.244 & 0.506 & 0.167 \\
\hline $\mathrm{K} / \mathrm{N}$ & 0.523 & 0.185 & 0.467 & 0.089 & 0.526 & 0.106 & 0.479 & 0.119 & 0.473 & 0.102 & 0.455 & 0.156 \\
\hline $\mathrm{K} / \mathrm{P}$ & 10.430 & 3.730 & 8.810 & 1.600 & 8.660 & 1.530 & 8.870 & 2.300 & 8.970 & 1.750 & 8.970 & 2.700 \\
\hline $\mathrm{K} / \mathrm{Ca}$ & 2.331 & 0.839 & 2.082 & 0.900 & 2.094 & 0.618 & 2.140 & 0.987 & 2.341 & 1.342 & 1.833 & 0.880 \\
\hline $\mathrm{K} / \mathrm{Mg}$ & 4.837 & 2.344 & 4.680 & 1.537 & 4.841 & 1.060 & 5.444 & 1.968 & 5.521 & 2.602 & 4.607 & 2.406 \\
\hline $\mathrm{Ca} / \mathrm{N}$ & 0.241 & 0.092 & 0.255 & 0.100 & 0.267 & 0.078 & 0.253 & 0.091 & 0.241 & 0.097 & 0.269 & 0.087 \\
\hline $\mathrm{Ca} / \mathrm{P}$ & 4.841 & 1.936 & 4.830 & 1.855 & 4.460 & 1.464 & 4.717 & 1.791 & 4.647 & 2.001 & 5.394 & 1.899 \\
\hline $\mathrm{Ca} / \mathrm{K}$ & 0.482 & 0.164 & 0.556 & 0.204 & 0.516 & 0.141 & 0.552 & 0.209 & 0.532 & 0.221 & 0.626 & 0.210 \\
\hline $\mathrm{Ca} / \mathrm{Mg}$ & 2.165 & 0.983 & 2.417 & 0.720 & 2.406 & 0.512 & 2.796 & 1.137 & 2.603 & 1.010 & 2.604 & 0.875 \\
\hline $\mathrm{Mg} / \mathrm{N}$ & 0.116 & 0.027 & 0.107 & 0.031 & 0.111 & 0.022 & 0.096 & 0.032 & 0.096 & 0.031 & 0.109 & 0.034 \\
\hline $\mathrm{Mg} / \mathrm{P}$ & 2.313 & 0.591 & 2.018 & 0.566 & 1.834 & 0.362 & 1.781 & 0.612 & 1.858 & 0.677 & 2.153 & 0.576 \\
\hline $\mathrm{Mg} / \mathrm{K}$ & 0.245 & 0.091 & 0.232 & 0.064 & 0.214 & 0.039 & 0.212 & 0.087 & 0.213 & 0.082 & 0.263 & 0.118 \\
\hline $\mathrm{Mg} / \mathrm{Ca}$ & 0.535 & 0.216 & 0.448 & 0.123 & 0.432 & 0.083 & 0.413 & 0.151 & 0.435 & 0.152 & 0.435 & 0.172 \\
\hline $\mathrm{z}(\mathrm{N})$ & 0.564 & 0.119 & 0.600 & 0.143 & 0.516 & 0.101 & 0.609 & 0.125 & 0.625 & 0.120 & 0.596 & 0.125 \\
\hline $\mathrm{z}(\mathrm{P})$ & -2.430 & 0.153 & -2.339 & 0.156 & -2.290 & 0.129 & -2.307 & 0.159 & -2.320 & 0.167 & -2.393 & 0.135 \\
\hline $\mathrm{z}(\mathrm{K})$ & -0.135 & 0.252 & -0.198 & 0.166 & -0.146 & 0.137 & -0.159 & 0.221 & -0.146 & 0.213 & -0.240 & 0.250 \\
\hline $\mathrm{z}(\mathrm{Ca})$ & -0.916 & 0.266 & -0.853 & 0.277 & -0.845 & 0.221 & -0.831 & 0.281 & -0.875 & 0.312 & -0.768 & 0.248 \\
\hline $\mathrm{z}(\mathrm{Mg})$ & -1.619 & 0.212 & -1.690 & 0.198 & -1.704 & 0.126 & -1.785 & 0.247 & -1.768 & 0.255 & -1.666 & 0.248 \\
\hline $\mathrm{g}(\mathrm{x})^{5}$ & 1.041 & 0.120 & 1.120 & 0.127 & 1.115 & 0.164 & 1.105 & 0.121 & 1.094 & 0.126 & 1.111 & 0.167 \\
\hline
\end{tabular}

${ }^{1 /}$ Parent \& Dafir (1992); ${ }^{2 /}>$ than mean +0.5 standard of deviation; ${ }^{3 /} \mathrm{MS}=$ dry matter; ${ }^{4 /}$ number of observations; ${ }^{5 /}$ geometric mean of contents.

tation by deficiency, represented by the positive response (p) or positive or zero (pz) of the fertilization response potential. The DRIS and the CND, on the other hand, presented similar performance at detecting these responses. The observation of stands where expressive nutrient concentrations (for example, IMS $<-15$ or $\mathrm{G}(\mathrm{X})>1.5$ ) are found, despite the low productivity, indicates that the cause of the low productivity probably lies in problems other than nutritional. On the other hand, in less concentrated stands (for example, IMS $=-3.15$ or $\mathrm{G}(\mathrm{X})=1.196$ ) where not all nutrient contents are greater than the mean values of the respective nutrients of the Virginópolis site (Table 5), M-DRIS did not detect any response, neither "p" nor "pz", either, whereas the DRIS and the CND gen- 
Table 6 - Chi-square test $\left(\chi^{2}\right)$ of the frequency of stands considered primary limiting by N, P, K, Ca, and Mg deficiency, in leaves of the aerial part of Eucalyptus grandis, subpopulation of low productivity ${ }^{1}$, using DRIS ${ }^{2}$, M-DRIS ${ }^{3}$, and $\mathrm{CND}^{4}$, by means of specific norms for each site, in the Central-Eastern region of the State of Minas Gerais.

\begin{tabular}{|c|c|c|c|c|c|c|c|}
\hline Site & Method & $\mathrm{N}$ & $\mathrm{P}$ & $\mathrm{K}$ & $\mathrm{Ca}$ & $\mathrm{Mg}$ & $\chi^{2}$ \\
\hline \multicolumn{8}{|c|}{ 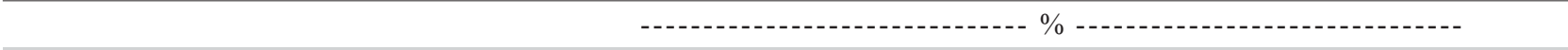 } \\
\hline \multirow{3}{*}{ Cocais $(n=129)$} & DRIS & 10.1 & 3.1 & 35.7 & 36.4 & 13.2 & $* *$ \\
\hline & M-DRIS & 5.4 & 1.6 & 34.9 & 31.8 & 12.4 & $* *$ \\
\hline & CND & 10.8 & 2.3 & 32.3 & 38.5 & 13.1 & $* *$ \\
\hline \multirow{3}{*}{ Piracicaba $(n=143)$} & DRIS & 9.0 & 10.3 & 30.3 & 27.6 & 20.7 & $* *$ \\
\hline & M-DRIS & 6.9 & 8.3 & 26.9 & 16.6 & 18.6 & $* *$ \\
\hline & $\mathrm{CND}$ & 10.5 & 8.5 & 28.8 & 26.8 & 20.9 & $* *$ \\
\hline \multirow{3}{*}{ Rio Doce $(\mathrm{n}=36)$} & DRIS & 5.6 & 16.7 & 25.0 & 25.0 & 19.4 & ns \\
\hline & M-DRIS & 8.3 & 16.7 & 19.4 & 16.7 & 16.7 & ns \\
\hline & CND & 19.4 & 13.9 & 25.0 & 19.4 & 19.4 & ns \\
\hline \multirow{3}{*}{ Sabinópolis (n=138) } & DRIS & 5.8 & 8.0 & 44.9 & 23.2 & 16.7 & $* *$ \\
\hline & M-DRIS & 5.1 & 5.1 & 42.0 & 19.6 & 12.3 & $* *$ \\
\hline & CND & 5.1 & 7.2 & 44.2 & 23.2 & 13.8 & $* *$ \\
\hline \multirow{3}{*}{ Santa Bárbara $(\mathrm{n}=121)$} & DRIS & 20.7 & 19.8 & 33.1 & 5.8 & 18.2 & $* *$ \\
\hline & M-DRIS & 21.5 & 16.5 & 32.2 & 2.5 & 13.2 & $* *$ \\
\hline & CND & 27.3 & 16.5 & 29.8 & 6.6 & 15.7 & $* *$ \\
\hline \multirow{3}{*}{ Virginópolis ( $\mathrm{n}=122$ ) } & DRIS & 13.1 & 13.1 & 41.0 & 18.0 & 12.3 & $* *$ \\
\hline & M-DRIS & 8.2 & 8.2 & 34.4 & 14.8 & 9.0 & $* *$ \\
\hline & $\mathrm{CND}$ & 13.1 & 13.9 & 36.9 & 18.9 & 10.7 & $* *$ \\
\hline \multirow{3}{*}{ All sites $(n=689)$} & DRIS & 11.2 & 11.0 & 36.3 & 22.7 & 16.5 & $* *$ \\
\hline & M-DRIS & 9.1 & 8.2 & 33.3 & 17.2 & 13.4 & $* *$ \\
\hline & CND & 13.4 & 9.7 & 33.9 & 22.9 & 15.2 & $* *$ \\
\hline
\end{tabular}

Table 7 - Frequency of stands with concordant diagnoses of the fertilization response potential ${ }^{1}$ for N, P, K, Ca, and Mg in Eucalyptus grandis, subpopulation of low productivity ${ }^{2}$, in the Central-Eastern region of Minas Gerais, among the methods DRIS ${ }^{3}$, M-DRIS ${ }^{4}$, and CND $^{5}$ by means of specific norms for each site, applied to the leaves.

\begin{tabular}{|c|c|c|c|c|c|c|c|c|c|c|c|c|c|c|c|c|c|c|}
\hline \multirow{2}{*}{ Site } & \multicolumn{6}{|c|}{ DRIS vs M-DRIS } & \multicolumn{6}{|c|}{ DRIS vs CND } & \multicolumn{6}{|c|}{ M-DRIS vs CND } \\
\hline & $\mathrm{N}$ & $\mathrm{P}$ & $\mathrm{K}$ & $\mathrm{Ca}$ & $\mathrm{Mg}$ & $\overline{\mathrm{Y}}^{6}$ & $\mathrm{~N}$ & $\mathrm{P}$ & $\mathrm{K}$ & $\mathrm{Ca}$ & $\mathrm{Mg}$ & $\overline{\mathrm{Y}}$ & $\mathrm{N}$ & $\mathrm{P}$ & $\mathrm{K}$ & $\mathrm{Ca}$ & $\mathrm{Mg}$ & $\overline{\mathrm{Y}}$ \\
\hline & --- & & & & & & & & 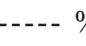 & $10=$ & & & & & & & & \\
\hline Cocais $(\mathrm{n}=129)$ & 51.2 & 58.1 & 73.6 & 78.3 & 68.2 & 65.9 & 79.8 & 81.4 & 91.5 & 95.3 & 89.9 & 87.6 & 41.9 & 55.8 & 66.7 & 75.2 & 71.3 & 62.2 \\
\hline Piracicaba $(n=143)$ & 51.7 & 65.7 & 69.2 & 63.6 & 69.9 & 64.1 & 81.8 & 83.2 & 88.1 & 90.2 & 91.6 & 87.0 & 65.7 & 74.1 & 72.7 & 72.0 & 75.5 & 72.0 \\
\hline Rio Doce $(n=36)$ & 63.9 & 63.9 & 75.0 & 61.1 & 63.9 & 65.6 & 72.2 & 83.3 & 91.7 & 86.1 & 86.1 & 83.9 & 69.4 & 55.6 & 75.0 & 63.9 & 66.7 & 66.1 \\
\hline Sabinópolis $(\mathrm{n}=138)$ & 53.6 & 61.6 & 73.2 & 61.6 & 68.1 & 63.6 & 72.5 & 84.1 & 90.6 & 84.1 & 92.8 & 84.8 & 59.4 & 71.0 & 79.0 & 67.4 & 71.7 & 69.7 \\
\hline Santa Bárbara $(\mathrm{n}=121)$ & 55.4 & 65.3 & 70.2 & 69.4 & 66.1 & 65.3 & 68.6 & 83.5 & 89.3 & 89.3 & 89.3 & 84.0 & 62.8 & 72.7 & 71.1 & 72.7 & 72.7 & 70.4 \\
\hline Virginópolis $(\mathrm{n}=122)$ & 63.1 & 60.7 & 73.8 & 69.7 & 63.1 & 66.1 & 86.1 & 89.3 & 89.3 & 89.3 & 91.0 & 89.0 & 63.1 & 63.9 & 77.0 & 73.8 & 67.2 & 69.0 \\
\hline All sites $(n=689)$ & 55.3 & 62.4 & 72.1 & 67.9 & 67.1 & 65.0 & 77.5 & 84.2 & 89.8 & 89.4 & 90.7 & 86.3 & 59.2 & 67.1 & 73.4 & 71.7 & 71.6 & 68.6 \\
\hline
\end{tabular}

erally identified some nutritional limitation by deficiency. Thus, the DRIS and the CND, in the suggested situation, would recommend fertilization, but that would not happen if the diagnosis were made by the M-DRIS. Therefore, if the limitations of these stands were really of nonnutritional nature, the use of the M-DRIS nutritional di- agnosis would appear more appropriate. However, if the low productivity were a consequence of nutritional problems as well, the application of the nutritional diagnosis through the DRIS or CND could help boost the productivity, if the non-nutritional problems were also solved. The productivity can be limited by macronutrients (S) and 
Table 8 - Frequency of stands with concordant diagnoses of the fertilization response potential ${ }^{1}$ for the nutrients considered together according to the situations (5, 4, 3, 2, 1, and 0), in Eucalyptus grandis, subpopulation of low productivity², in the Central-Eastern region of Minas Gerais, among the methods DRIS ${ }^{3}, \mathrm{M}-\mathrm{DRIS}{ }^{4}$, and $\mathrm{CND}^{5}$ by means of specific norms for each site, applied to the leaves.

\begin{tabular}{|c|c|c|c|c|c|c|c|c|c|c|c|c|c|c|c|c|c|c|}
\hline \multirow{3}{*}{ Site } & \multicolumn{6}{|c|}{ DRIS vs M-DRIS } & \multicolumn{6}{|c|}{ DRIS vs CND } & \multicolumn{6}{|c|}{ M-DRIS vs CND } \\
\hline & \multicolumn{18}{|c|}{ - Nutrients diagnosed equally ${ }^{6}-1$} \\
\hline & 5 & 4 & 3 & 2 & 1 & 0 & 5 & 4 & 3 & 2 & 1 & 0 & 5 & 4 & 3 & 2 & 1 & 0 \\
\hline & & & & & & & & & & & & & & & & & & \\
\hline Cocais $(n=129)$ & 19.4 & 26.4 & 25.6 & 21.7 & 7.0 & 0.0 & 61.2 & 17.8 & 18.6 & 2.3 & 0.0 & 0.0 & 14.0 & 22.5 & 32.6 & 24.0 & 5.4 & 1.6 \\
\hline Piracicaba $(n=143)$ & 18.2 & 24.5 & 27.3 & 19.6 & 10.5 & 0.0 & 55.9 & 28.0 & 11.2 & 4.9 & 0.0 & 0.0 & 26.6 & 30.1 & 27.3 & 9.8 & 5.6 & 0.7 \\
\hline Rio Doce $(\mathrm{n}=36)$ & 11.1 & 33.3 & 30.6 & 22.2 & 2.8 & 0.0 & 50.0 & 25.0 & 22.2 & 0.0 & 2.8 & 0.0 & 11.1 & 38.9 & 25.0 & 19.4 & 5.6 & 0.0 \\
\hline Sabinópolis $(n=138)$ & 13.8 & 27.5 & 31.9 & 16.7 & 10.1 & 0.0 & 47.8 & 32.6 & 15.2 & 4.3 & 0.0 & 0.0 & 21.0 & 33.3 & 23.9 & 16.7 & 5.1 & 0.0 \\
\hline Santa Bárbara $(\mathrm{n}=121)$ & 20.7 & 23.1 & 28.1 & 19.0 & 8.3 & 0.8 & 46.3 & 33.1 & 16.5 & 2.5 & 1.7 & 0.0 & 23.1 & 33.1 & 21.5 & 17.4 & 5.0 & 0.0 \\
\hline Virginópolis $(\mathrm{n}=122)$ & 17.2 & 25.4 & 36.1 & 13.9 & 6.6 & 0.8 & 61.5 & 24.6 & 11.5 & 2.5 & 0.0 & 0.0 & 18.9 & 31.1 & 32.8 & 11.5 & 4.9 & 0.8 \\
\hline All sites $(n=689)$ & 17.4 & 25.8 & 29.8 & 18.4 & 8.3 & 0.3 & 54.3 & 27.1 & 14.9 & 3.2 & 0.4 & 0.0 & 20.3 & 30.5 & 27.4 & 16.0 & 5.2 & 0.6 \\
\hline
\end{tabular}

Table 9 - Frequency of stands with concordant diagnoses of the fertilization response potential ${ }^{1}$ (p and n) in Eucalyptus grandis, subpopulation of low productivity ${ }^{2}$ in the Central-Eastern region of Minas Gerais, among the methods DRIS $^{3}$, M-DRIS ${ }^{4}$, and CND 5 , by means of specific norms for each site, applied to the leaves.

\begin{tabular}{|c|c|c|c|}
\hline Site & Method & $\mathrm{p}$ & $\mathrm{n}$ \\
\hline & & $-\cdots---$ & 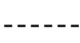 \\
\hline \multirow{3}{*}{ Cocais $(n=129)$} & DRIS $v s$ M-DRIS & 83.7 & 38.3 \\
\hline & DRIS vs CND & 96.1 & 83.2 \\
\hline & M-DRIS vs CND & 80.6 & 36.3 \\
\hline \multirow{3}{*}{ Piracicaba(n=143) } & DRIS vs M-DRIS & 75.4 & 48.9 \\
\hline & DRIS vs CND & 91.6 & 86.4 \\
\hline & M-DRIS vs CND & 78.1 & 51.2 \\
\hline \multirow{3}{*}{ Rio Doce $(n=36)$} & DRIS vs M-DRIS & 74.3 & 60.0 \\
\hline & DRIS vs CND & 77.1 & 82.9 \\
\hline & M-DRIS vs CND & 63.9 & 57.6 \\
\hline \multirow{3}{*}{ Sabinópolis(n=138) } & DRIS vs M-DRIS & 78.3 & 35.6 \\
\hline & DRIS vs CND & 89.1 & 85.2 \\
\hline & M-DRIS vs CND & 85.6 & 38.4 \\
\hline \multirow{3}{*}{ Santa Bárbara $(n=121)$} & DRIS vs M-DRIS & 79.0 & 40.2 \\
\hline & DRIS vs CND & 85.7 & 82.5 \\
\hline & M-DRIS vs CND & 81.9 & 41.9 \\
\hline \multirow{3}{*}{ Virginópolis(n=122) } & DRIS vs M-DRIS & 73.6 & 45.7 \\
\hline & DRIS vs CND & 93.3 & 91.5 \\
\hline & M-DRIS vs CND & 72.6 & 47.4 \\
\hline \multirow{3}{*}{ All sites $(\mathrm{n}=689)$} & DRIS vs M-DRIS & 77.8 & 42.7 \\
\hline & DRIS vs CND & 90.4 & 85.6 \\
\hline & M-DRIS vs CND & 79.0 & 43.9 \\
\hline
\end{tabular}

${ }^{1 /}$ Wadt et al. (1998b); ${ }^{2 /} \leq$ than mean +0.5 standard deviation; ${ }^{3 /}$ Beaufils (1973), considering the IEN ${ }_{\mathrm{m}}$ proposed by Wadt et al. (1998b);

${ }^{4 /}$ Hallmark et al. (1987), using the equation of Jones (1981) for the calculation of the functions; ${ }^{5 /}$ Parent \& Dafir (1992); p = primary limiting by deficiency; $\mathrm{n}=$ primary limiting by excess.

by micronutrients, for which the respective norms have not been calculated.

Depending on the chosen form of comparison and the nutrient concentration degree in the trees, very different results can be obtained in relation to the concordance of the methods. The M-DRIS was more sensitive to identify stands with non-nutritional problems, com- pared to the other methods. In stands with lower nutrient contents and some nutrient concentrations below those of the reference population, the M-DRIS does not detect this limitation, in spite of its nutritional character. In such cases, using diagnosis methods might be more adequate, even though they have lower sensitivity to identify nonnutritional problems. 
Table 10 - Productivity (IMA), indices of primary and mean nutritional balance (IEN ${ }_{\mathrm{m}}$ ), nutrient contents, fertilization response potential ${ }^{1}$ of $\mathrm{N}, \mathrm{P}, \mathrm{K}, \mathrm{Ca}$, and $\mathrm{Mg}$ using the methods DRIS${ }^{2}$, M-DRIS ${ }^{3}$, and $\mathrm{CND}^{4}$, applied to the leaves, in Eucalyptus grandis stands, selected from the low-productivity ${ }^{5}$ subpopulation from the Virginópolis site, in the Central-Eastern region of Minas Gerais.

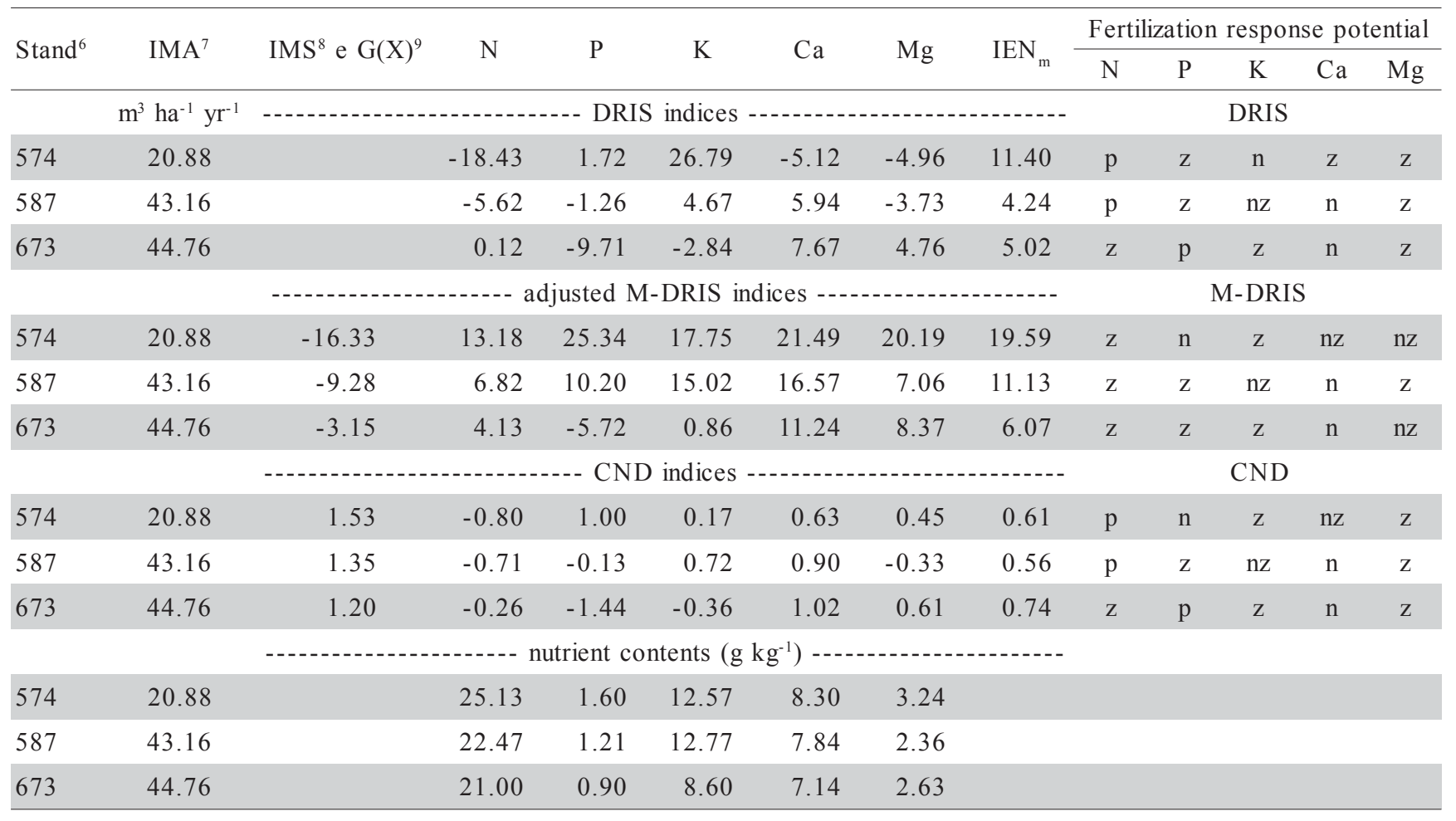

${ }^{1 /}$ Wadt et al. (1998b); ${ }^{2 /}$ Beaufils (1973), considering the IEN ${ }_{\mathrm{m}}$ proposed by por Wadt et al. (1998b); ${ }^{3 /}$ Hallmark et al. (1987), using the equation of Jones (1981) to calculate the functions; ${ }^{4 /}$ Parent \& Dafir (1992); ${ }^{5 /} \leq$ than mean +0.5 standard deviation; ${ }^{6 /}$ Silva (2001); ${ }^{7 /}$ mean annual increase of the stem volume; ${ }^{8 /}$ dry matter index, regarding the M-DRIS; ${ }^{9 /}$ geometric mean of the nutritional composition, regarding the CND.

\section{REFERENCES}

AITCHISON, J. The statistical analysis of compositional data. Journal of the Royal Statistical Society. Series B, v.44, p.139-177, 1982.

BAILEY, J.S.; BEATTIE, J.A.M.; KILPATRICK D.J. The diagnosis and recommendation integrated system (DRIS) for diagnosing the nutrient status of grassland swards: I. Model establishment. Plant and Soil, v.197, p.127-135, 1997.

BALDOCK, J.O.; SCHULTE, E.E. Plant analysis with standardized scores combines DRIS and sufficiency range approaches for corn. Agronomy Journal, v.88, p.448-456, 1996.

BEAUFILS, E.R. Diagnosis and recommendation integrated system (DRIS). Pietermaritizburg: University of Natal, 1973. 132p. (Soil Science Bulletin, 1).

BLACK, C.A. Soil fertility evaluation and control. Londow. Lewis Publisher, 1993. 746p.

CALDWELL, J.O.N.; SUMNER, M.E.; VAVRINA, C.S. Development and testing of preliminary foliar DRIS norms for onions. Hortscience, v.29, p.1501-1504, 1994.

CRESTE, E.J.; TIRITAN, C.S.; LEBEDENCO, A. Avaliação nutricional de diferentes genótipos de milho através do DRIS. In: CONGRESSO BRASILEIRO DE CIÊNCIA DO SOLO, 28., Londrina, 2001. Resumo. Londrina: SBCS, 2001. p.159.

ELWALI, A.M.O.; GASCHO, G.J. Soil testing, foliar analysis, and DRIS as guide for sugarcane fertilization. Agronomy Journal, v.76, p.466470, 1984.

HALLMARK, W.B.; WALWORTH, J.L.; SUMNER, M.E.; de MOOY, C.J.; PESEK, J.; SHAO, K.P. Separating limiting and non-limiting nutrients. Journal of Plant Nutrition, v.10, p.1381-1390, 1987.
HALLMARK, W.B.; BEVERLY, R.B.; PARKER, M.B.; ADAMS, J.F.; BOSWELL, F.C.; OHKI, K.; SHUMAM, L.M.; WILSON, D.O. Evaluation of soybean zinc and manganese requirements by the M-DRIS and sufficiency range methods. Agronomy Journal, v.81, p.770-776, 1989.

HALLMARK, W.B.; BEVERLY, R.B.; SUMNER, M.E.; de MOOY, C.J.; MORRIS, H.F.; PESEK, J.; FONTENOT, J.D. Soybean phosphorus and potassium requirement evaluation by three M-DRIS data bases. Agronomy Journal, v.82, p.323-328, 1990.

HARTZ, T.K.; MIYAO, E.M.; VALENCIA, J.G. DRIS evaluation of the nutritional status of processing tomato. Hortscience, v.33, p.830-832, 1998.

HOLLAND, D.A. The interpretation of leaf analysis. Journal of the Horticultural Science \& Biotecnology, v.41, p.311-329, 1966.

JARREL, W.M.; BEVERLY, R.B. The dilution effect in plant nutrition studies. Advances in Agronomy, v.34, p.197-224, 1981.

JONES, C.A. Proposed modifications of the Diagnosis and Recommendation Integrated System (DRIS) for interpreting plant analysis. Communications in Soil Science and Plant Analysis, v.22, p.785-794, 1981.

KHIARI, L.; PARENT, L.E.; TREMBLAY, N. The phosphorus compositional nutrient diagnosis range for potato. Agronomy Journal, v.93, p.815-819, 2001.

PARENT, L.E.; CAMBORIUS, A.N.; MUHAWENIMANA, A. Multivariate diagnosis of nutrient imbalance in potato crops. Soil Science Society of America Journal, v.58, p.1432-1438, 1994.

PARENT, L.E.; DAFIR, M. A theoretical concept of compositional nutrient diagnosis. Journal of the American Society for Horticultural Science, v.117, p.239-242, 1992. 
PAYNE, G.G.; RECHCIGL, J.E.; STEPHENSON, R.L. Development of Diagnosis and Recommendation Integrated System norms for Bahiagrass. Agronomy Journal, v.82, p.930-934, 1990.

RAGHUPATHI, H.B.; BHARGAVA, B.S. Diagnosis of nutrient element norms for grape. Journal of Plant Nutrition, v.22, p.219-227, 1999.

REIS JR., R.A.; MONNERAT, P.H. Diagnose nutricional da cana-de-açúcar através do sistema integrado de diagnose e recomendação (DRIS). In: REUNIÃO BRASILEIRA DE FERTILIDADE DO SOLO E NUTRIÇÃO DE PLANTAS, 23., Caxambú, 1998. Resumos. Caxambú, 1998. p.751.

SILVA, G.G.C. Diagnose nutricional do eucalipto pelo DRIS, M-DRIS e CND. Viçosa: UFV, 2001. 132p. (Dissertação - M.S.).

WADT, P.G.S. Os métodos da chance matemática e do Sistema Integrado de Diagnose e Recomendação (DRIS) na avaliação nutricional de plantios de eucalipto. Viçosa: UFV, 1996. 123p. (Tese - Doutorado).
WADT, P.G.S.; NOVAIS, R.F.; ALVAREZ V., V.H.; FONSECA, S.; BARROS, N.F. Valores de referência para macronutrientes em eucalipto obtidos pelos métodos DRIS e chance matemática. Revista Brasileira de Ciência do Solo, v.22, p.685-692, 1998a.

WADT, P.G.S.; NOVAIS, R.F.; ALVAREZ V., V.H.; FONSECA, S.; BARROS, N.F.; DIAS, L.E. Três métodos de cálculo do DRIS para avaliar o potencial de resposta à adubação de árvores de eucalipto. Revista Brasileira de Ciência do Solo, v.22, p.661-666, 1998b.

Received November 22, 2002

Accepted July 07, 2004 